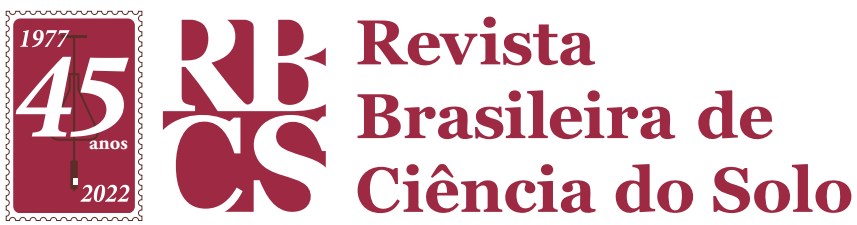

Division - Soil Processes and Properties | Commission - Soil Biology

\title{
Soil-plant-microbiota interactions to enhance plant growth
}

\author{
Camila Gazolla Volpiano ${ }^{(1)}$ (D), Bruno Britto Lisboa ${ }^{(2)}$ (D), Jackson Freitas Brilhante de \\ São José( ${ }^{(2)}(\mathbb{D})$, Anelise Beneduzi ${ }^{(2)}\left(\mathbb{D}\right.$, Camille Eichelberger Granada ${ }^{(3)}(\mathbb{D})$ and Luciano \\ Kayser $\operatorname{Vargas}^{(2) *}$ iD \\ (1) Universidade Federal do Rio Grande do Sul, Instituto de Biociências, Departamento de Genética, Porto \\ Alegre, Rio Grande do Sul, Brasil. \\ (2) Secretaria Estadual da Agricultura, Pecuária e Desenvolvimento Rural, Departamento de Diagnóstico e \\ Pesquisa Agropecuária, Porto Alegre, Rio Grande do Sul, Brasil. \\ (3) Universidade do Vale do Taquari, Programa de Pós-graduação em Biotecnologia, Lajeado, Rio Grande do \\ Sul, Brasil.
}

\section{* Corresponding author: E-mail: luciano-kayser@ agricultura.rs.gov.br}

Received: August 06, 2021 Approved: November 05, 2021

How to cite: Volpiano CG, Lisboa BB, São José JFB, Beneduzi A, Granada CE, Vargas LK. Soil-plant-microbiota interactions to enhance plant growth. Rev Bras Cienc Solo. 2022;46:e0210098.

https://doi.org/10.36783/18069657rbcs20210098

Editors: José Miguel Reichert (iD and Sidney Stürmer (1D.

Copyright: This is an open-access article distributed under the terms of the Creative Commons Attribution License, which permits unrestricted use, distribution, and reproduction in any medium, provided that the original author and source are credited.
ABSTRACT: The nature of the soil is shaped by the presence of roots and the soil microbiota. Bacteria, archaea and fungi profoundly alter plant growth and, in turn, depend on root exudation of carbon-rich and energy-yielding compounds. The microbial communities act as facilitators of plant processes by secreting plant growth regulators, solubilizing minerals, providing $\mathrm{N}$ for plant growth, altering plant immune responses and competing with plant pathogens. Characterizing and engineering the processes driven by the multiple microbial taxa that make up a "plant growth-promoting soil" represents an ecologically friendly solution that may lead to unprecedented increases in agronomic efficiency. This review outlines the characteristics of soil-plant-microbiota interactions that would lead to enhanced plant growth and the importance of characterizing the soil microbial communities with metabarcoding and shotgun metagenomics allied to machine learning analytics. Although much is still needed to be understood about soil microbial ecology, it is possible to choose the best soil management practices to take advantage of beneficial microbial activity with our current knowledge.

Keywords: plant growth-promotion, soil suppressiveness, solubilization of nutrients, nitrogen fixation, soil microbiome. 


\section{INTRODUCTION}

Attempts to increase crop yield by manipulating beneficial soil microorganisms can be traced back for centuries, even before the existence of microbes be recognized (Vessey, 2003). It was the case of mixing different soils as means of "remedying defects and adding heart to the soil", as related by the Greek philosopher Theophrastus (372-287 BC) (Tisdale and Nelson, 1975). One of the consequences of this practice was the introduction of beneficial microorganisms to the soil, which was more evident when soil from previous legume crop was mixed with the legume seeds or with soil in which non-legumes were grown (Bashan, 1998).

The isolation and selection of efficient rhizobia gained the attention of researchers by the end of the 19th century, when it was realized that root-nodule bacteria were responsible for the process by which atmospheric nitrogen is assimilated by legume plants (Willems, 2006). Around the same time, it was acknowledged that soil contains a large and diverse microscopic living population, which would be later defined as microbial biomass (Stockdale and Brookes, 2006). Soil microbial biomass is an agent of transformation and cycling of organic matter and plant nutrients in soils, acting both as a sink and a source of nutrients, besides being involved in the formation and stabilization of aggregates, detoxification of pollutants and being an early indicator of soil quality (Brookes et al., 1982; Angers et al., 1993; Vargas and Scholles, 2000; Lisboa et al., 2012; Prudnikova et al., 2021). Therefore, the importance of microbial biomass and activity for soil functioning has been recognized for several decades and can be summarized by the famous definition "the eye of the needle, through which all organic matter must pass as it is broken down to the simple inorganic components that plants can use again" (Jenkinson, 1977).

Considering that microbial biomass includes beneficial and deleterious microorganisms, a specific group has become the object of increasing interest by researchers in the last decades. By the end of the 1970s, Kloepper and coworkers coined the term plant growth-promoting rhizobacteria (PGPR) to describe rhizosphere isolated pseudomonads that, following seed inoculation, rapidly colonized plants roots and increased crop yield (Kloepper and Schroth, 1978; Kloepper et al., 1980). After this pioneering study, the concept was adopted and developed by several researchers, so that the number of publications associated with PGPR has been growing exponentially since the 1990s (Figure 1) (Finkel et al., 2017). More recently, the concept of PGPR was extended to any bacteria (PGPB) or any microorganism (PGPM) exhibiting plant growth-promoting (PGP) traits - such as nitrogen fixation, phosphate and potassium solubilization, production of siderophores, indolic compounds, and 1-aminocyclopropane-1-carboxylate (ACC) deaminase or that lessen or prevent the deleterious effects of one phytopathogenic organism - and that is proved to be effective in enhancing plant biomass production (Figure 2) (Beneduzi et al., 2012; Ma, 2019).

In this review, we propose extending this concept to the whole soil microbiota, rather than restraining it to individual microbial strains or a few microbial genera. In this context, we discuss how soil microbiota may affect plant growth and strategies to shape the composition of the soil microbiome to perform the role of a "plant growth-promoting soil" (PGPS).

\section{Biological control of plant pathogens}

Biological control is an indirect mechanism of plant growth promotion since it involves the release of bioactive molecules by PGPM, which minimize or cease the harmful effects of phytopathogens, instead of directly improving plant growth (Datta and Chakrabartty, 2014; Vargas et al., 2017; Volpiano et al., 2018). At the same time, every soil has some level of resistance against plant diseases (Anees et al., 2010). This ability of a soil to avoid the onset of a disease in a susceptible plant host, even in the presence of a significant inoculum density of the pathogen, is called soil suppressiveness (Klein et al., 2011). The 


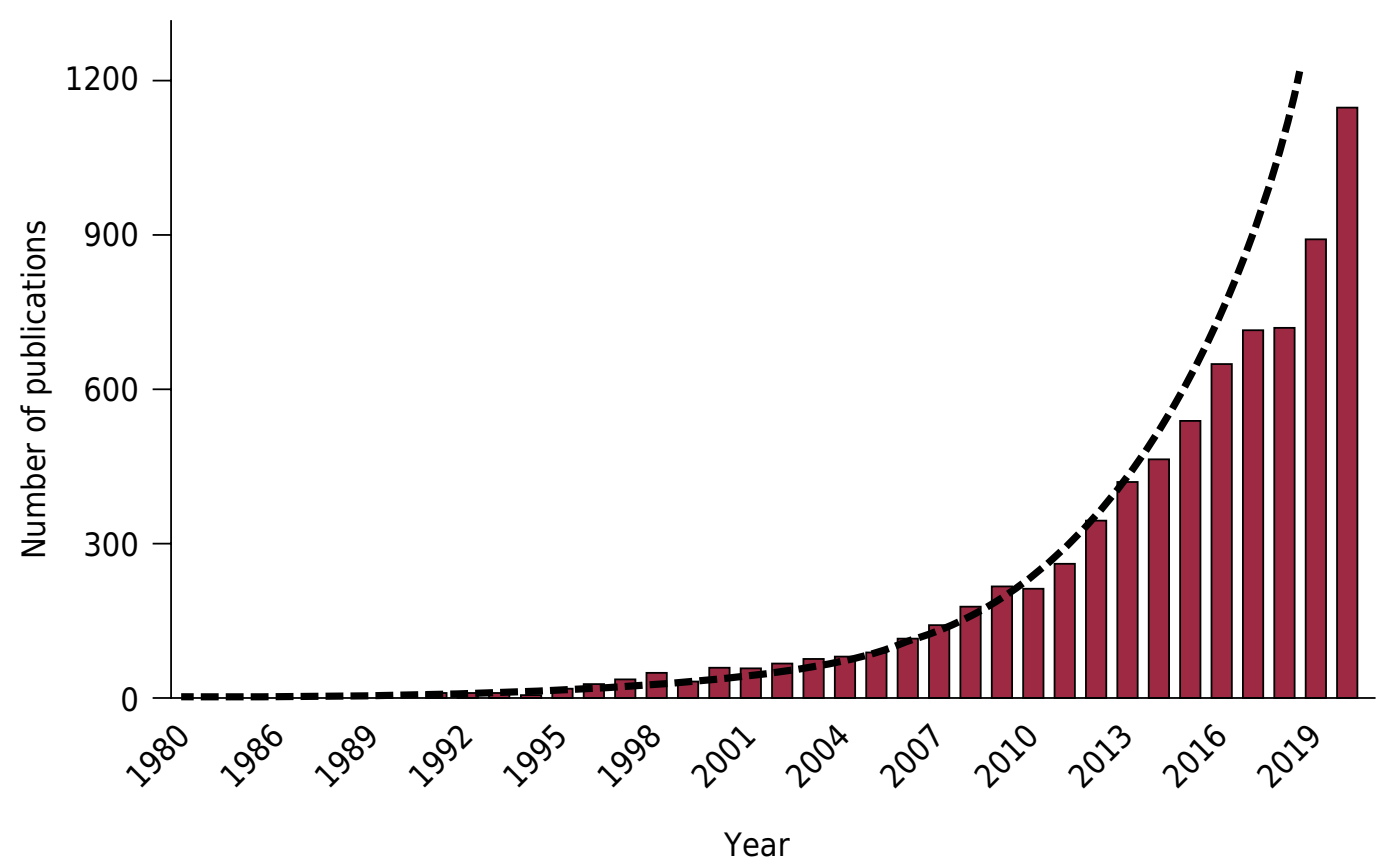

Figure 1. Number of publications regarding plant growth-promoting microbes per year since 1980. The data was collected on Scopus database using the terms "plant growth-promoting rhizobacteria" or "plant growth-promoting bacteria" or "plant growth-promoting microbes" on title, abstract and keywords.

opposite is called soil conduciveness, so that soil suppressiveness varies from soil to soil, in a range from highly conducive to strongly suppressive soils (Anees et al., 2010).

Although abiotic factors, such as soil physicochemical properties, may contribute to the suppression of a given phytopathogen, suppressiveness is essentially a phenomenon mediated by soil microorganisms, since sterilization processes turn suppressive soils into conducive soils (Garbeva et al., 2004; Lisboa et al., 2015; Campos et al., 2016). Different studies compared microbial communities of suppressive and conductive soils and identified that a high abundance of different bacterial and fungal groups could be related to suppressive ones (Table 1 ).

Soil suppression is attributable to several mechanisms, including induction of plant systemic resistance and direct inhibition of pathogens by the overall or specific microbial activity of a soil and can be classified as general or specific suppression (Weller et al., 2002). General suppression is the widespread but limited ability of soils to suppress growth or activity of soil-borne pathogens. It is associated with the total microbial biomass and activity in the soil. In contrast, specific suppression is related to the effects of individual or select groups of microorganisms during some stage in the life cycle of a pathogen. Suppressive soils result from a combination of both general and specific suppression and can be altered by soil management.

A large number of publications have shown that microbial biomass and activity are strongly influenced by soil management. Typically, soil tillage methods and culture systems that increase soil organic matter will also increase microbial biomass and activity and, consequently, general suppression. Campos et al. (2016) observed that soil organic matter content was positively correlated with the percentage of suppression against Fusarium graminearum. Likewise, microbial biomass and microbial respiratory activity were strongly correlated with soil suppressiveness and were higher in no-tillage and the cropping system with higher plant residue input. High input cropping systems and no-tillage are also expected to have higher water retention capacity and lower temperatures in the soil (Blanco-Canqui and Ruis, 2018; Dai et al., 2021a). Döring et al. (2020) found out that combined heat and drought stress reduced soil suppressiveness 


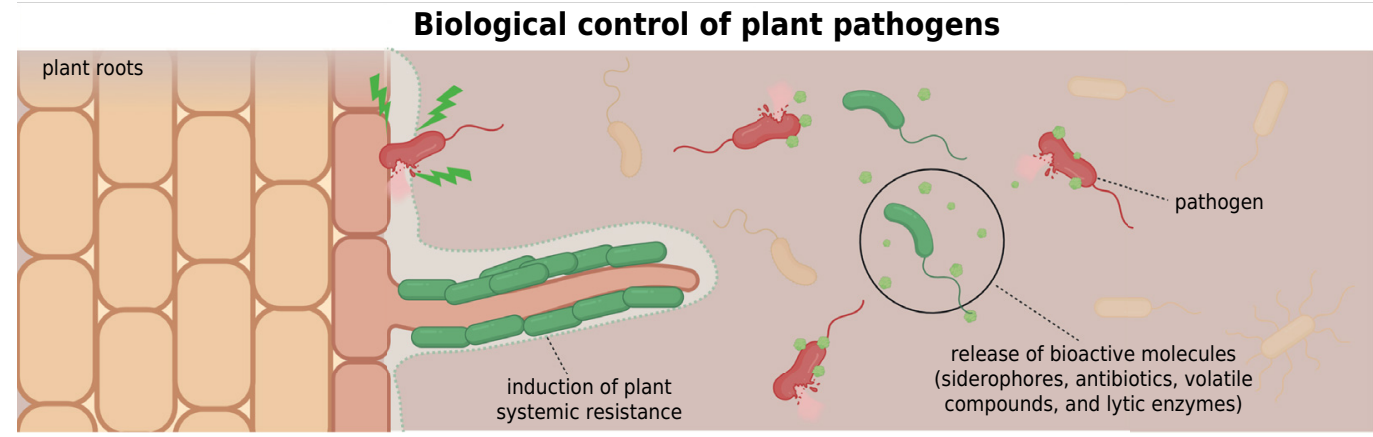

Production of plant growth regulators

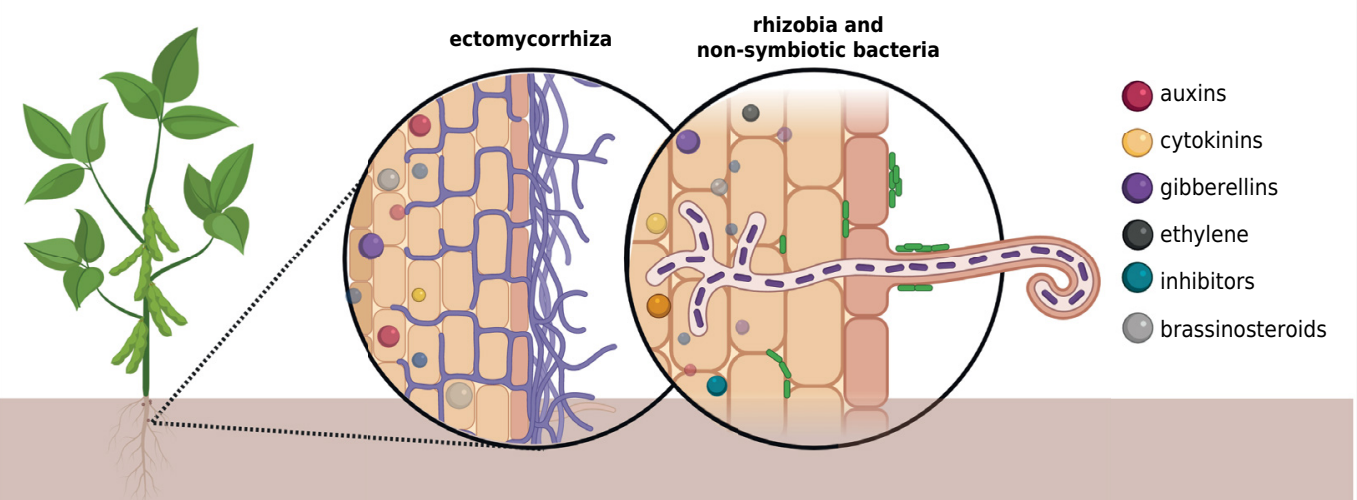

Solubilization of phosphorus, potassium, and micronutrients

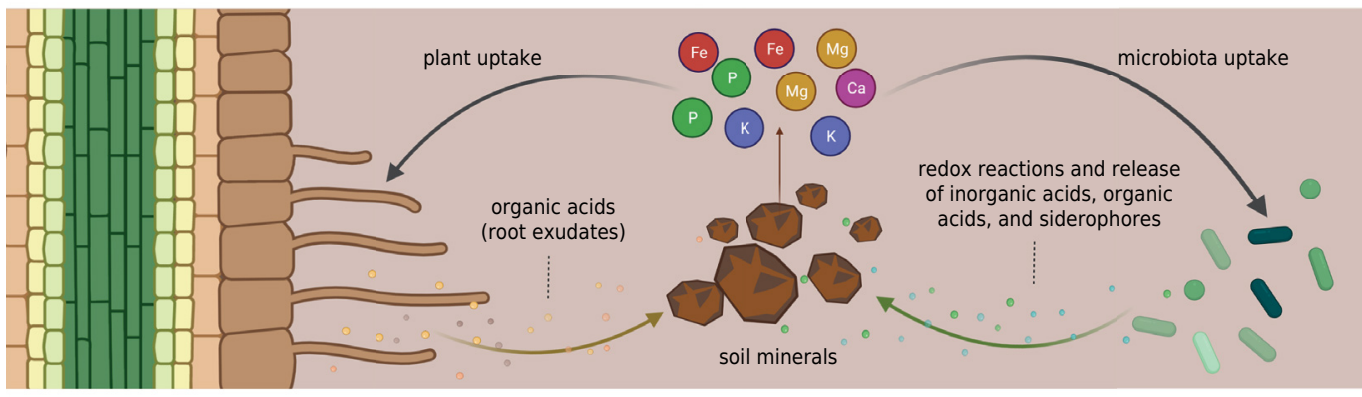

Biological nitrogen fixation

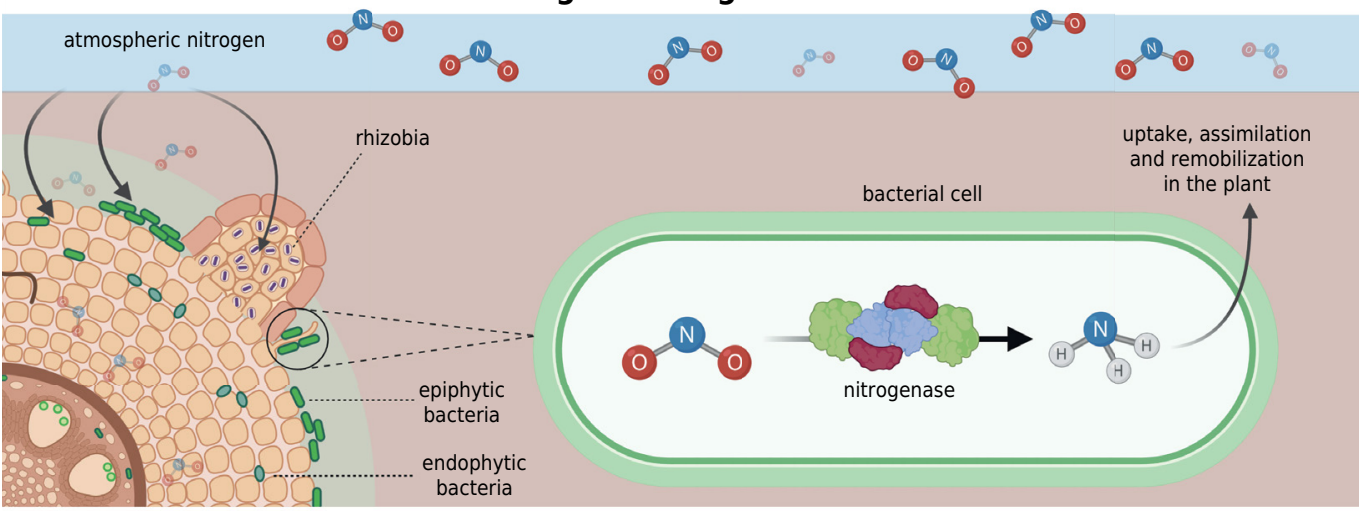

Figure 2. Examples of soil microbiota behavior capable of promoting plant growth. On suppressive plant growth-promoting soil (PGPS), the beneficial microorganisms can release antibiotics, volatile compounds, and lytic enzymes causing damage to phytopathogens cells, besides eliciting plant induced systemic resistance and competing with space and nutrients. The microbiota living on PGPS soils and plant rhizosphere may stimulate germination, development of the root architecture and plant biomass resulting in better yield parameters through the production of plant growth regulators. Weathering PGPM from the PGPS soils microbiota can increase the nutrient availability to plants by promoting the dissolution of minerals. These microorganisms could act using redox reactions and producing compounds such as organic and inorganic acids. Biological nitrogen fixation by legumes and associative, endosymbiotic and endophytic nitrogen fixation in non-legumes play major roles in reducing the use of synthetic nitrogen fertilizer in agriculture. Image created with BioRender.com. 
Table 1. Main microbial OTUs identified in high throughput sequencing studies positively related to suppressiveness of different pathogens

\begin{tabular}{|c|c|c|c|}
\hline Crop characteristics & Phathogen & OTUs positively related to supressiveness & Reference \\
\hline $\begin{array}{l}\text { 30-years of conventional } \\
\text { tillage (C) and no-tillage } \\
\text { (S) management }\end{array}$ & $\begin{array}{l}\text { Fusarium } \\
\text { graminearum }\end{array}$ & $\begin{array}{l}\text { Bacteria: Chitinophagaceae, } \\
\text { Acidobacteriaceae, Microbacterium, and } \\
\text { Burkholderiaceae }\end{array}$ & Campos et al. (2016) \\
\hline $\begin{array}{l}\text { 3-year (C) and 15-year (S) } \\
\text { monoculture of strawberry }\end{array}$ & $\begin{array}{l}\text { Fusarium oxysporum } \\
\text { S4-7 }\end{array}$ & $\begin{array}{l}\text { Bacteria: Actinobacteria, Proteobacteria, } \\
\text { Acidobacteria, Nitrospirae and } \\
\text { Gemmatimonadetes. }\end{array}$ & Cha et al. (2016) \\
\hline
\end{tabular}

Fallow field for several (S) and few $(C)$ years
Fusarium wilt

Fusarium wilt

(S and C) Vanilla long-term continuous cropping with similar soil characteristics.

(S) tillage and no-tillage soybean; (C) formaldehyde Heterodera glycines treated soil

(S and C) Tobacco field

Ralstonia spp.
(S and C) Crop producing agroecosystems
Fusarium oxysporum
Fungy: Acremonium, Chaetomium,

Cladosporium, Clonostachys, Fusarium,

Ceratobasidium, Mortierella, Penicillium,

Scytalidium, and Verticillium

Bacteria: Adhaeribacter, Massilia, Microvirga,

Siegel-Hertz et al. (2018)

Rhizobium, Geobacter, Rhizobacter,

Arthrobacter, Amycolatopsis, Rubrobacter,

Paenibacillus, and Stenotrophomonas

Fungy: Zygomycota and Basidiomycota

Bacteria: Acidobacteria, Verrucomicrobia, Actinobacteria and Firmicutes

Xiong et al. (2017)

Fungy: Helotiales, unclassified Orbiliomycetes, Chaetothyriales, and unclassified Ascomycota

Bacteria: Pseudomonadales and

Hu et al. (2017)

Enterobacteriales

Bacteria: Acidobacteria, BRC1, Crenarchaeota, Euryarchaeota, Ignavibacteriae, Latescibacteria, Pacearchaeota, Synergistetes, and

Yang et al. (2017) Woesearchaeota

Bacteria: Actinobacteria, Firmicutes and Acidobacteria

Trivedi et al. (2017)

Bacteria: Chthonomonas, putative genera

(S and C) Banana orchards Fusarium wilt named Gp4 and Gp5, Pseudomonas, and Tumebacillus

Shen et al. (2015)

Fungy: Ascomycota Bacteria: Firmicutes

Zeng et al. (2021)

(S) suppressive soil sample; (C) conductive soil sample.

against Pythium pathogen species. On the other hand, the authors also found that the recovery of suppressiveness over a given time was negatively related to stress tolerance. In this context, we could assume that soils under high input cropping systems and no-tillage could be more resistant to heat and drought and keep their suppressiveness for a longer time. But, once affected, they would take a longer time to regain functionality.

Specific suppression is the antagonistic activity of certain microorganisms against a pathogen within the soil. It results from definite mechanisms, such as the production of siderophores, antibiotics, volatile compounds and lytic enzymes. It is also referred to as transferable suppression, since it can be acquired by inoculation with natural suppressive soil, suppressive compost, or inoculant products (Simon and Sivasithamparam, 1989; Pane et al., 2013; Fu et al., 2017).

In addition to inoculation, specific suppression can be stimulated by soil management. Lisboa et al. (2015) reported that no-tillage soil samples exhibited higher F. graminearum fungistasis compared with conventional tillage. The different cropping systems also showed significant differences in soil fungistasis, being higher in the cropping systems with legumes. The authors considered that antibiosis and production of siderophores were the 
main mechanisms accounting for the reduction of the pathogen development. Likewise, Campos et al. (2016) observed that soil suppressiveness, as well as the activity of the chitin degrading enzyme $\beta$-glucosaminidase, were significantly higher in no-tillage and oat+vetch / corn+cowpea rotation. When evaluating the soil bacterial microbiome, the authors found specific groups associated with soil suppressiveness, microbial biomass, microbial respiratory activity and $\beta$-glucosaminidase activity. Those groups included Chitinophagaceae, Acidobacteriaceae, Microbacterium and Burkholderiaceae, while Steroidobacter, Kouleothrixaceae, Oxalobacteraceae and Gemmatimonadetes were associated with conducive soils from conventional tillage.

Fertilization can also affect soil suppressiveness, either increasing or decreasing disease severity. Excessive fertilizer applications can increase plant susceptibility to diseases. For instance, Crozier et al. (2000) noted that $\mathrm{N}$ excess resulted in more Rhizoctonia stem canker incidence in potato plants. On the other hand, Bongiorno et al. (2019) assessed soil suppressiveness in 101 soil samples from 10 long-term field experiments and observed that, at some sites, organic farming and mineral fertilization increased soil suppressiveness. When the positive impact of the mineral fertilization occurred, it was linked to its enhancing effect on plant biomass, which also increases root biomass and, in turn, can have a stimulatory effect on microbial activity. Chen et al. (2020) described that, upon organic fertilization, the rhizosphere bacterial community strongly suppressed mycelial growth and spore germination of Fusarium spp., with a significantly higher peanut yield. On the contrary, the potential fungal pathogens dominated the fungal microbiome in the rhizosphere upon chemical fertilization. The authors concluded that long-term organic fertilization could be used to build up a microbial community that can suppress the invasion of fungal pathogens.

In summary, suppressiveness characteristics of PGPSs appear to be more related to coordinated activities of multiple microbial groups rather than individual PGPMs. The use of crop rotation, conservation tillage and management practices focused on the soil microbiota will allow engineering the soil living components, preventing the onset of plant diseases.

\section{Production of plant growth regulators}

Plant growth regulators are organic molecules analogous to plant hormones, which, at low concentrations, cause a physiological response and influence plant development (Vargas et al., 2017). Such compounds can be grouped into six different categories: (i) auxins, (ii) cytokinins, (iii) gibberellins, (iv) ethylene (v), a group called inhibitors, which includes abscisic acid, phenolics, and alkaloids (Ferguson and Lessenger, 2006), and (vi) brassinosteroids (Bajguz and Tretyn, 2003). Among them, the production of auxins is considered the most common feature, as more than $80 \%$ of the soil bacteria can produce auxins, especially indoleacetic acid (IAA), besides indolebutyric acid or other similar compounds derived from tryptophan metabolism (Solano et al., 2008; Brígido and Glick, 2015; Gang et al., 2019). Auxins are plant growth hormone that stimulates cell division and elongation. As a result, plants inoculated with IAA-producing PGPM exhibit an enhanced proliferation of lateral roots and root hairs (Yousef, 2018), leading to a more extensive root architecture development (Dazzo and Yanni, 2006). Other studies reported the increase in seed germination parameters (Schlindwein et al., 2008; Granada et al., 2014; de Souza et al., 2016; São José et al., 2019), plant biomass (Chen et al., 2017; Daraz et al., 2021), and yield parameters (Gadagi et al., 2004) as a result of microbial IAA production.

Another widely studied PGPM trait is the production of 1-aminocyclopropane-1-carboxylate (ACC) deaminase, a microbial enzyme that reduces ethylene levels in plant root tissue (Vargas et al., 2017). According to Glick et al. (1998), the enzyme acts in the rhizosphere and degrades ACC, exuded by plant roots, to ammonia and $\alpha$-ketobutyrate. As a result, the level of ACC outside the plant decreases, forming a gradient from the plant interior 
to its exterior. To maintain the equilibrium between internal and external ACC levels, the plant must exude increasing amounts of ACC. Consequently, the level of ACC within the plant is reduced and the inhibitory action of ethylene is decreased. Thus, plants influenced by ACC deaminase-producing PGPM are expected to have longer roots and shoots (Glick et al., 2007).

An increasing number of studies show the beneficial effects of inoculating IAA and ACC deaminase-producing PGPM strains on different agronomically important crops. For example, bacteria from the genera Achromobacter, Arthrobacter, Azospirillum, Bacillus, Burkholderia, Herbaspirillum, Paenibacillus and Pseudacidovorax, and fungi from the genera Pisolithus and Trichoderma, among others, are reported to increase plant growth of eucalypt, corn, melon, rice and sunflower due to IAA and ACC deaminase production (Ditengou and Lapeyrie, 2000; Martínez-Medina et al., 2011; Arruda et al., 2013; Souza et al., 2013; Ambrosini et al., 2015; Zerrouk et al., 2019; de Souza et al., 2021).

Only a few studies have investigated the impact of soil management on IAA levels and ACC deaminase activity in bulk and rhizosphere soils. Smaill at al. (2010) studied the longterm effects of $\mathrm{N}$ fertilization and chemical weed control on IAA and ACC deaminase in a Pinus radiata plantation. Chemical weed control and fertilization treatments increased IAA concentrations and ACC deaminase activity in bulk soil. Growth of $P$. radiata was positively correlated with IAA concentrations, while ACC deaminase activity positively correlated with $P$. radiata growth only in the absence of $\mathrm{N}$ fertilization. Changes in soil IAA levels due to chemical weed control depend on the herbicide active ingredient. Atrazine, for instance, may strongly inhibit IAA production both in soil and in rhizosphere, an inhibition that is more evident in the presence of mineral fertilizers (Rossi et al., 1984). Similar effect was produced by the herbicide glyphosate and the fungicide kitazin, as demonstrated by Shahid and Khan (2020). Both pesticides were inhibitory to IAA synthesizing ability and protein synthesis by beneficial soil bacteria, such as Pseudomonas fluorescens, Burkholderia cepacia, Azotobacter vinelandii, Rhizobium leguminosarum and Bradyrhizobium japonicum.

The influence of cropping systems on soil ACC deaminase activity was described by Saad et al. (2018). The authors studied the effect of the nickel-hyperaccumulator Alyssum murale in monoculture or intercropped with a legume (Vicia sativa) on the bacterial diversity and physico-chemical properties of an ultramafic soil. The activity of ACC deaminase showed the highest value in the intercropping system, while $A$. murale alone with mineral fertilization showed low activity and was the nearest to the value of the bare soil. The authors inferred that intercropping or rotation treatments increased ACC deaminase activity probably due to the presence of a mixed plant cover that could favor the development of a bacterial community possessing this function.

Amendment with organic materials may stimulate IAA production in the soil. Zhang et al. (2009) evaluated the application of biosolids from a wastewater treatment plant and noted an increased IAA content in soil amended with biosolids, as compared with the unamended control. This increase could be partly explained by the biosolid direct contribution, as it contained IAA. However, as the net increase of IAA was much higher, more than twice the biosolid IAA content, it was concluded that the major contribution of the biosolid was enhancing the IAA microbial production and/or root exudation. In addition, the increase of IAA in soil was accompanied by a greater leaf concentration of this hormone in tall fescue (Lolium arundinaceum).

Soil physicochemical properties are thought to have less influence on auxin production than the soil microbiome functional profile (Sarwar et al., 1992). Lu et al. (2021) identified 54 OTUs positively correlated with IAA concentration. The authors also verified that IAA concentrations were more significant in bulk soil than in the rhizosphere and that microbiome modification can also change soil phytohormone concentration. The authors point out that, while the microbial capacity to produce phytohormones can be stimulated, 
the microbial degradation of these phytohormones in the rhizosphere can also be increased, weakening or even eliminating the expected beneficial effects. Taking this into account, management practices intending to manipulate phytohormone levels should consider how to regulate not only their production, but also their degradation.

\section{Solubilization of phosphorus, potassium and micronutrients}

Several studies have described the role of soil microorganisms in releasing nutrients from minerals and rocks (Granada et al., 2018). The solubilization of $P$ is the best characterized one (Ribeiro et al., 2020), although $\mathrm{K}$ solubilization has recently gained more interest (Verma et al., 2017). Other nutrients, namely $\mathrm{Ca}, \mathrm{Mg}, \mathrm{Fe}, \mathrm{Mn}$ and $\mathrm{Zn}$, are also released by bacterial and fungal activity (Altomare et al., 1999; Granada et al., 2013; Ribeiro et al., 2020). Microbial activity leads to the solubilization of nutrients by redox reactions, acidification of the environment, chelation of cations and competition with phosphate for adsorption sites in the soil (Altomare et al., 1999; Yadav and Verma, 2012). All these mechanisms depend on organic matter metabolism (Lovley and Chapelle, 1995; Schmitt et al., 2018).

Soil acidification alters ion solubility, which disrupts ion concentration equilibrium in the mineral-solution interface by directing the balance in favor of mineral dissolution (Ribeiro et al., 2020). It can be either the result of proton extrusion associated with ammonium assimilation, or of organic acids production, which is considered the main mechanism of P solubilization (Yadav and Verma, 2012). Due to this reason, solubilization of mineral $\mathrm{P}$ is thought to be more efficient in alkaline soils, in which Ca-P complexes are present, than in naturally acid soils in which phosphates are complexed with Fe and Al ions (Solano et al., 2008; Yadav and Verma, 2012). In acid soils, low-molecular weight organic acids, produced as byproducts of the metabolism of carbon, increase $P$ availability for plants, not by acidification, but by inhibiting $P$ adsorption in reactive sites of the soil (Schmitt et al., 2018). Andrade et al. (2003) showed the capacity of organic acids in reducing $\mathrm{P}$ adsorption and precipitation due to the blockage of $\mathrm{P}$ sorption sites.

Microbial solubilization of nutrients can be altered by soil management. As rule, soil rich in organic matter will favor microbial growth and, as a consequence, microbial nutrient solubilization (Alori et al., 2017). Azziz et al. (2012) found a smaller abundance of phosphate solubilizing bacteria (PSB) in no-tillage continuous cropping than in a permanent pasture and in a previous agricultural field, which was restored to natural grassland. Fast-growing heterotrophic bacteria populations were also higher in permanent pasture. Similarly, Khanghahi et al. (2021) isolated and identified bacterial strains from wheat (Triticum aestivum L.) fields in soils under conventional tillage and no-tillage. The authors showed that most of the beneficial bacterial isolates belonged to the no-tillage soil, including several isolates with the remarkable capability to solubilize insoluble inorganic $P, K$ and $Z n$.

Besides confirming the influence of tillage, Bolo et al. (2021) showed how fertilization and plant residue management could impact $P$ solubilization. Reduced tillage increased the abundance of $P$ solubilizers in relation to conventional tillage. Furthermore, residue addition, as well as corn-soybean intercropping, increased the abundance of $P$ solubilizers. Conversely, inorganic fertilizers reduced the abundance and liming reduced the richness of $\mathrm{P}$ solubilizing microbial species.

The application of ground silicate rocks can be an alternative to mineral fertilizers, mainly by supplying $\mathrm{P}, \mathrm{K}, \mathrm{Ca}, \mathrm{Mg}$ and micronutrients to the plants (Martins et al., 2015). Silva et al. (2017) evaluated the effects of long-term rock phosphate fertilization on corn rhizosphere microbiome composition. Compared to triple superphosphate-treated soil, soil amended with Araxa apatite showed higher enrichment in several bacterial and fungal taxa previously described as crucial for $\mathrm{P}$ solubilization and acquisition. The 
results suggest changes in the microbial community composition associated with the type of phosphate fertilization.

A higher population of nutrient solubilizing microorganisms does not necessarily mean higher solubilization rates. Pastore et al. (2020a) evaluated the P solubilization in soils derived from different parent materials. Despite the abundance of PSB was higher in the P-poor soils, gross P solubilization rates were much higher in the P-rich parent material soil. The solubilization rates in the rich site, which were originated from basalt, were also followed by significantly higher amounts of organic acids. Additionally, Pastore et al. (2020b) demonstrated that phosphate release from hydroxyapatite was higher than from goethite. So, soil nutrient deficiency can select microorganisms with a high ability to solubilize inorganic nutrients (Alori et al., 2017). Still, weathering rate seems to be mostly dependent on nutrient levels in parent material (Pastore et al., 2020a) or in rock amendments (Pastore et al., 2020b), besides the specific surface area of the saprolite (Brucker et al., 2020). Moreover, microbial weathering of minerals is strongly limited by C availability (Brucker et al., 2020; Pastore et al., 2020b). Brucker et al. (2020) concluded that the solubilization of $\mathrm{P}$ from apatite was not affected by $\mathrm{P}$ availability, indicating that this process is not or not exclusively controlled by the microbial need for $P$, but it is limited by the availability of easily decomposable $\mathrm{C}$.

Several reports have proven the effectiveness of soil microorganisms in releasing nutrients from minerals and rocks. Developing effective microbial inoculants for solubilization of nutrients and better management of soil microbial communities may help us move towards more sustainable fertilization practices and build up PGPSs.

\section{Non-symbiotic nitrogen fixation}

According to the original definition, rhizobacteria are free-living bacteria that colonize the root zone (Deka et al., 2015), and, thus, symbiotic nitrogen-fixing bacteria are usually not considered PGPR due to the highly specific nature of their interaction (Dobbelaere et al., 2003). Although less efficient, non-symbiotic nitrogen-fixing PGPR, with different degrees of association with plants, are of significant importance in agriculture. Fixation rates by non-symbiotic bacteria are highly variable, ranging from near zero to $60 \mathrm{~kg} \mathrm{ha}^{-1} \mathrm{yr}^{-1}$ of $\mathrm{N}$ in natural ecosystems (Cleveland et al., 1999). In agricultural soils, fixation rates, as well as the abundance, diversity, and composition of the non-symbiotic diazotrophic community, are highly sensitive to various soil physicochemical properties (Dai et al., 2021b) and, consequently, to soil management.

Nitrogen fixation is a highly energy-demanding process, so increasing $C$ availability is generally thought to stimulate it. Nevertheless, little or no effect was observed in other studies. Li et al. (2021) evaluated the impact of tillage systems on wheat rhizosphere diazotrophs. Tillage significantly affected the assembly and composition of the rhizosphere diazotrophic community, as most of keystone taxa were enriched under conservation tillage. There was a significant correlation between community composition and soil organic carbon (SOC), emphasizing the importance of improved substrate availability for the rhizosphere diazotrophic community under conservation tillage. In exchange, Hsu and Buckley (2009) studied a corn field under different tillage and crop residue management and found that the rate of nitrogen fixation was significantly lower in no-tillage with soil-surface crop residue maintenance than in all other treatments. This treatment also showed the lowest diversity and richness of the diazotrophic community. More than the amount of $C$, the quality of the soil organic matter seems to be more determinant to nitrogen fixation. Several authors report a positive correlation between soil $\mathrm{C}: \mathrm{N}$ ratio and the diversity and activity of the diazotrophic community, so that higher $\mathrm{C}: \mathrm{N}$ values could result in a competitive advantage for free-living diazotrophs (Mirza et al., 2014; Yang et al., 2019; Chen et al., 2021; Dai et al., 2021b). 
Application of fertilizers, either chemical or organic, can favor nitrogen fixation by improving soil fertility, yet the response to nutrients availability is highly variable. Although nitrogen availability can have stimulatory effects on diazotrophic diversity (Poly et al., 2001), most of the recent studies evidence its negative effects on nitrogen fixation and diazotrophic abundance (Reardon et al., 2014; Zheng et al., 2019; Xiao et al., 2020; Chen et al., 2021; Dai et al., 2021b). Potassium can have negative (Hsu and Buckley, 2009), little or no effect (Tang et al., 2017), while phosphorus, in general, has stimulatory effects over nitrogen fixation (Tang et al., 2017; Zheng et al., 2019; Zheng et al., 2019).

Organic fertilizers and crop residue management can also affect the nitrogen-fixation process in variable ways. Yang et al. (2019) concluded that soil incorporation of rice straw repressed nifH gene abundance, but increased $\alpha$-diversity; while Chen et al. (2021) found that wheat mulch, along with chemical fertilization, increased the abundance and richness of diazotrophs. Liao et al. (2018) found that the combined use of chicken manure and chemical fertilizers can improve the activity of the diazotrophic community. Even so, Dai et al. (2021b) evaluated combinations of chemical and organic fertilizers, made of milk vetch (Astragalus sinicus L.) or pig manure, and observed that the increasing percentage of organic fertilizer reduced the diazotrophic abundance. The authors also found that potential nitrogen fixation rates were higher in unfertilized and chemical fertilized treatments than under organic fertilization in the early rice season. In contrast, opposite results were observed in the late rice season. This was attributed to the decrease in soil C: $\mathrm{N}$ ratio caused by fertilization in different seasons. The authors found a positive correlation between potential nitrogen fixation and soil $\mathrm{C}: \mathrm{N}$, suggesting that higher soil $\mathrm{C}: \mathrm{N}$ ratio could favor free-living $\mathrm{N}_{2}$ fixation.

Seasonality and cropping systems are other factors affecting the diazotrophic community. As expected, legumes in crop mixtures or rotations result in increased abundance of nifH gene and dominance of rhizobial symbiont. Reardon et al. (2014) found greater nifH abundance in soil cropped with pea (Pisum sativum L.) than that with wheat. The abundance of nifH gene was also higher in continuous cropping of soybean than in continuous cropping of corn, with $B$. japonicum as the dominant diazotrophic species, according to Zou et al. (2020). Additionally, the authors also noted that the abundance of the nifH gene was increased when soybean and corn were cropped in rotation compared to continuous cropping. Similarly, Gao et al. (2021) showed that rape-cucumber intercropping increased the abundance of the nifH gene, diazotrophic diversity, and richness, which were higher than in the monoculture. However, cropping season had a more significant effect than intercropping. Seasonal variability was also considered by Reardon et al. (2014) as the main factor influencing diazotrophic communities.

As described above, the response of the non-symbiotic nitrogen fixation process to abiotic factors is highly variable and difficult to predict. In this context, Hsu and Buckley (2009) suggest that the variation in diazotrophic community structure has a greater impact on $\mathrm{N}$-fixation rates than soil characteristics. In this context, recent studies have shown that microbial communities harbor keystone taxa, which drive community composition and function (Banerjee et al., 2018). Identifying nitrogen-fixing keystone taxa (Dai et al., 2021b), their interconnected network (Alleman et al., 2021), and increasing their abundance (Banerjee et al., 2018) can be the most efficient way to increase nitrogen fixation rates and improve plant productivity. In this case, inoculation can be used as a tool not only to introduce desirable diazotrophs or increase their abundance, but also to shape the microbiome. Mawarda et al. (2020) reviewed the literature and examined the impact of microbial inoculation in 108 studies analyzed, out of which $86 \%$ showed that inoculants modify soil microbial communities in the short or long term. As demonstrated by Costa et al. (2018), an efficient inoculant is not the one with the most invasive microorganisms, but the one that results in an enrichment of specific pre-existing taxa. 


\section{Soil microbiome monitoring and prediction of crop productivity}

In recent years, advances in DNA sequencing technology and data analysis immensely broadened the understanding of microbial ecology, enabling the so-called microbiome revolution (Craig et al., 2016; Cryan and Dinan, 2019). Consequently, many researchers consider microbiome analysis to be one of the most useful tools in agriculture in the future (Sessitsch et al., 2019; Xie et al., 2019; Souza et al., 2020).

Microbiome can be defined as the sum of microorganisms, their genomes and metabolic interactions in a given ecological niche (Pothmann et al., 2019). Second-generation or next-generation sequencing (NGS), in which multiple parallel sequencing of millions of DNA fragments are performed simultaneously, made the analysis of the whole microbiome possible (Grada and Weinbrecht, 2013). At the same time, bioinformatics pipelines can process a large number of sequences in a short time, performing the quantification of copies and the taxonomic assignment from sequencing data.

From metagenomic analysis, it is possible to identify the keystone taxa, the networks and the functional profiles of soil microbiome. Keystone taxa are fundamental to soil microbial community structure and function, as they can modify biotic connectivity and change the response of the microbial community to abiotic factors and their relationships with plants (Yang et al., 2021). Zheng et al. (2021) studied two contrasting tobacco fields, one conducive and the other suppressive to Ralstonia solanacearum bacterial wilt disease (Table 1). Network analysis revealed that the suppressive soil formed a more complex and highly interactive bacterial network. Pseudomonas was the most abundant genus in both the suppressive soil and healthy roots, followed by Streptomyces and Gaiella. At the same time, Ralstonia, Kluyvera, Terrabacter, Ochrobactrum, and Massilia were considered the keystones to the network structure of the conducive soil. In the fungal community, the abundance of Fusarium showed a positive correlation with the abundance of Ralstonia. Dai et al. (2021b) found that most keystone taxa under different fertilization regimes in paddy soils belonged to Bradyrhizobium and Geobacter genera. The authors emphasize that keystone taxa are highly connected, and their removal may lead to a significant change in the composition and function of the microbiome. So, those genera are suggested to play an essential role in maintaining their network and nitrogen fixation stability. Importantly, when performing microbiome studies, one should consider temporal dynamics and soil spatial heterogeneity to obtain a representative set of samples from the studied area (Nannipieri et al., 2019).

Bioinformatics tools, such as PICRUSt, Tax4Fun and Vikodak, can also predict the functional profile of microbiomes by using marker gene data and a database of reference genomes (Ortiz-Estrada et al., 2019). Chaudhari et al. (2020) used Tax4Fun, from 16S rRNA gene amplicon sequencing of pea rhizosphere and bulk soils, to predict the functional contributions of bacterial communities. Rhizosphere samples revealed higher predicted abundance of genes involved in nitrogen fixation, siderophore production, IAA production, and phosphate solubilization than bulk soil samples. Similarly, Jo et al. (2020) used PICRUSt to predict the function of the soil bacterial community after inoculation with Bacillus thuringiensis KNU-07 in pepper (Capsicum annuum). The microbial community composition was altered by inoculation, as well as the predicted function. In the first weeks, the abundance of predicted genes related to sporulation and germination was elevated. After six weeks post-inoculation, the abundance of KNU-07 decreased, pathways related to energy metabolism and the metabolism of cofactors and vitamins were increased, resulting in better nutrition for inoculated plants.

After determining the composition of microorganisms present in a soil or root sample through NGS, there are still challenges to extracting useful information from the big data obtained. The development and application of machine learning (ML) approaches have revolutionized our ability to create predictive models in many areas. For example, in medical research, many studies have shown that methods based on machine learning 
can accurately predict the association of gut microbiome with various disease states (Saulnier et al., 2011; He et al., 2018; Dadkhah et al., 2019; Seneviratne et al., 2020). Chang et al. (2017) recently used a similar approach to predict soybean productivity based on data from bulk soil microbiome. While no significant association was found between crop productivity and the soil chemical characteristics, crop productivity could be explained by the taxa variance in the bulk soil microbiome. The authors identified a higher abundance of Bradyrhizodium and Gammaproteobacteria in higher productivity areas; and more Actinobacteria, Ascomycota, Planctomycetales and Streptophyta in lower productivity areas. An ML model successfully predicted productivity based on the microbiome composition with 79 \% of accuracy. According to Souza et al. (2020), computational methods, including $\mathrm{ML}$, will boost the approaches of screening and identifying beneficial microorganisms, while determining the best combination of microorganisms for the desired plant phenotype.

The ML will help selecting the most suitable soil management practices to magnify the beneficial activity of indigenous soil microorganisms. The application of ML to microbiome data may represent a breakthrough in soil microbiology research, promoting the understanding of the functioning of PGPSs, leading to improve agricultural productivity, less environmental impact, food security and sustainability (Gebbers and Adamchuk, 2010; Liakos et al., 2018; Kamilaris and Prenafeta -Boldú, 2018).

\section{CONCLUSIONS}

Soil microbial community acts as a plant growth-promoting agent, which we could call a plant growth-promoting soil. We presented the most usual plant growth-promoting mechanisms and discussed how soil management could impact the microbial community composition and activity. Although rapidly changing technologies are transforming our knowledge about soil microbial ecology, much is still needed to be understood. On the other hand, it is possible to choose the best methods to take advantage of beneficial soil microbial activity with our current knowledge.

\section{AUTHOR CONTRIBUTIONS}

Conceptualization: (D) Bruno Britto Lisboa (equal), (D) Camila Gazolla Volpiano (equal) and (D) Luciano Kayser Vargas (equal).

Writing - original draft: (D) Anelise Beneduzi (supporting), (D) Bruno Britto Lisboa (supporting), (D) Camila Gazolla Volpiano (equal), (D) Camille Eichelberger Granada (supporting), (D) Jackson Freitas Brilhante de São José (supporting) and (D) Luciano Kayser Vargas (equal).

\section{REFERENCES}

Alleman AB, Mohammed YA, McVay KA, Khan QA, Carr P, Miller J, Miller Z, Torrion J, Lamb P, Mus F, Chen C, Peters JW. Drivers of diazotroph community structure and co-occurrence in a Northern Great Plains pulse crop rotation system. Appl Soil Ecol. 2021;157:103737. https://doi.org/10.1016/j.apsoil.2020.103737

Alori ET, Glick BR, Babalola OO. Microbial phosphorus solubilization and its potential for use in sustainable agriculture. Front Microbiol. 2017;8:971. https://doi.org/10.3389/fmicb.2017.00971

Altomare C, Norvell WA, Björkman T, Harman GE. Solubilization of phosphates and micronutrients by the plant-growth-promoting and biocontrol fungus Trichoderma harzianum Rifai 1295-22. Appl Environ Microbiol. 1999;65:2926-33. https://doi.org/10.1128/AEM.65.7.2926-2933.1999 
Ambrosini A, Stefanski T, Lisboa BB, Beneduzi A, Vargas LK, Passaglia LMP. Diazotrophic bacilli isolated from the sunflower rhizosphere and the potential of Bacillus mycoides $\mathrm{B} 38 \mathrm{~V}$ as biofertiliser. Ann Appl Biol. 2015;168:93-110. https://doi.org/10.1111/aab.12245

Andrade FV, Mendonça ES, Alvarez VH, Novais RF. Addition of organic and humic acids to Latosols and phosphate adsorption effects. Rev Bras Cienc Solo. 2003;27:1003-11. https://doi.org/10.1590/S0100-06832003000600004

Anees M, Tronsmo A, Edel-Hermann V, Gautheron N, Faloya V, Steinberg C. Biotic changes in relation to local decrease in soil conduciveness to disease caused by Rhizoctonia solani. Eur J Plant Pathol. 2010;126:29-41. https://doi.org/10.1007/s10658-009-9517-0

Angers DA, Bissonnette N, Lègére A, Samsom N. Microbial and biochemical changes induced by rotation and tillage in a soil under barley production. Can J Soil Sci. 1993;73:39-50. https://doi.org/10.4141/cjss93-004

Arruda LM, Beneduzi A, Martins AF, Lisboa, BB, Lopes CN, Bertolo F, Passaglia LMP, Vargas LK. Screening of rhizobacteria isolated from maize (Zea mays L.) in Rio Grande do Sul State (South Brazil) and analysis of their potential to improve plant growth. Appl Soil Ecol. 2013;63:15-22. https://doi.org/10.1016/j.apsoil.2012.09.001

Azziz G, Bajsa N, Haghjou T, Taulé C, Valverde A, Igual JM, Arias A. Abundance, diversity and prospecting of culturable phosphate solubilizing bacteria on soils under crop-pasture rotations in a no-tillage regime in Uruguay. Appl Soil Ecol. 2012;61:320-6. https://doi.org/10.1016/j.apsoil.2011.10.004

Bajguz A, Tretyn A. The chemical characteristic and distribution of brassinosteroids in plants. Phytochemistry. 2003;62:1027-46. https://doi.org/10.1016/s0031-9422(02)00656-8

Banerjee S, Schlaeppi K, van der Heijden MGA. Keystone taxa as drivers of microbiome structure and functioning. Nat Rev Microbiol. 2018;16:567-76. https://doi.org/10.1038/s41579-018-0024-1

Bashan Y. Inoculants of plant growth-promoting bacteria for use in agriculture. Biotechnol Adv. 1998;16:729-70. https://doi.org/10.1016/S0734-9750(98)00003-2

Beneduzi A, Ambrosini A, Passaglia LMP. Plant growth-promoting rhizobacteria (PGPR): Their potential as antagonists and biocontrol agents. Genet Mol Biol. 2012;35:1044-51. https://doi.org/10.1590/S1415-47572012000600020

Blanco-Canqui H, Ruis SJ. No-tillage and soil physical environment. Geoderma. 2018;326:164-200. https://doi.org/10.1016/j.geoderma.2018.03.011

Bolo P, Kihara J, Mucheru-Muna M, Njeru EM, Kinyua M, Sommer R. Application of residue, inorganic fertilizer and lime affect phosphorus solubilizing microorganisms and microbial biomass under different tillage and cropping systems in a Ferralsol. Geoderma. 2021;390:114962. https://doi.org/10.1016/j.geoderma.2021.114962

Bongiorno G, Postma J, Bünemann EK, Brussaard L, Goede RGM, Mäder P, Tamm L, Thuerig B. Soil suppressiveness to Pythium ultimum in ten European long-term field experiments and its relation with soil parameters. Soil Biol Biochem. 2019;133:174-87. https://doi.org/10.1016/j.soilbio.2019.03.012

Brígido C, Glick BR. Phytoremediation using rhizobia. In: Ansari AA, Gill SS, Gill R, Lanza GR, Newman L, editors. Phytoremediation: management of environmental contaminants. New York: Springer; 2015. p. 95-114. https://doi.org/10.1007/978-3-319-10969-5_9

Brookes PC, Powlson DS, Jenkinson DS. Measurement of microbial biomass phosphorus in soil. Soil Biol Biochem. 1982;14:319-29. https://doi.org/10.1016/0038-0717(82)90001-3

Brucker E, Kernchen S, Spohn M. Release of phosphorus and silicon from minerals by soil microorganisms depends on the availability of organic carbon. Soil Biol Biochem. 2020;143:107737. https://doi.org/10.1016/j.soilbio.2020.107737

Campos SB, Lisboa BB, Camargo FAO, Bayer C, Sczyrba A, Dirksen P, Albersmeier A, Kalinowski J, Beneduzi A, Costa PB, Passaglia LMP, Vargas LK, Wendisch VF. Soil suppressiveness and its relations with the microbial community in a Brazilian subtropical agroecosystem under different management systems. Soil Biol Biochem. 2016;96:191-7. https://doi.org/10.1016/j.soilbio.2016.02.010 
Cha J-Y, Han S, Hong H-J, Cho H, Kim D, Kwon Y, Kwon S-K, Crüsemann M, Lee YB, Kim JF, Giaever G, Nislow C, Moore BS, Thomashow LS, Weller DM, Kwak Y-S. Microbial and biochemical basis of a Fusarium wilt-suppressive soil. ISME J. 2016;10:119-29. https://doi.org/10.1038/ismej.2015.95

Chang HX, Haudenshield JS, Bowen CR, Hartman GL. Metagenome-wide association study and machine learning prediction of bulk soil microbiome and crop productivity. Front Microbiol. 2017;8:519. https://doi.org/10.3389/fmicb.2017.00519

Chaudhari D, Rangappa K, Das A, Layek J, Basavaraj S, Kandpal BK, Shouche Y, Rahi P. Pea (Pisum sativum L.) plant shapes its rhizosphere microbiome for nutrient uptake and stress amelioration in acidic soils of the North-East region of India. Front Microbiol. 2020;11:968. https://doi.org/10.3389/fmicb.2020.00968

Chen B, Luo S, Wu Y, Ye J, Wang Q, Xu X, Pan F, Khan KY, Feng Y, Yang X. The effects of the endophytic bacterium Pseudomonas fluorescens Sasm05 and IAA on the plant growth and cadmium uptake of Sedum alfredii Hance. Front Microbiol. 2017;8:2538. https://doi.org/10.3389/fmicb.2017.02538

Chen D, Wang X, Zhang W, Zhou Z, Ding C, Liao Y, Li X. Persistent organic fertilization reinforces soil-borne disease suppressiveness of rhizosphere bacterial community. Plant Soil. 2020;452:313-28. https://doi.org/10.1007/s11104-020-04576-3

Chen S, Xiang X, Ma H, Penttinen P, Zhao J, Li H, Gao R, Zheng T, Fan G. Straw mulching and nitrogen fertilization affect diazotroph communities in wheat rhizosphere. Front Microbiol. 2021;12:658668. https://doi.org/10.3389/fmicb.2021.658668

Cleveland CC, Townsend AR, Schimel DS, Fisher H, Howarth RW, Hedin LO, Perakis SS, Latty EF, von Fischer JC, Elseroad A, Wasson MF. Global patterns of terrestrial biological nitrogen $\left(\mathrm{N}_{2}\right)$ fixation in natural ecosystems. Global Biogeochem Cycles. 1999;13:623-45. https://doi.org/10.1029/1999GB900014

Costa PB, Campos SB, Albersmeier A, Dirksen P, Dresseno ALP, Santos OJAP, Milani KML, Etto RM, Battistus AG, Costa ACPR, Oliveira ALM, Galvão CW, Guimarães VF, Sczyrba A, Wendisch VF, Passaglia LMP. Invasion ecology applied to inoculation of plant growth promoting bacteria through a novel SIMPER-PCA approach. Plant Soil. 2018;422:467-78. https://doi.org/10.1007/s11104-017-3492-6

Craig JM, Logan AC, Prescott SL. Natural environments, nature relatedness and the ecological theater: connecting satellites and sequencing to shinrin-yoku. J Physiol Anthropol. 2016;35:1. https://doi.org/10.1186/s40101-016-0083-9

Crozier CR, Creamer NG, Cubeta MA. Fertilizer management impacts on stand establishment, disease, and yield of Irish potato. Potato Res. 2000;43:49-59. https://doi.org/10.1007/BF02358513

Cryan JF, Dinan TG. Talking about a microbiome revolution. Nat Microbiol. 2019;4:552-3. https://doi.org/10.1038/s41564-019-0422-9

Dadkhah E, Sikaroodi M, Korman L, Hardi R, Baybick J, Hanzel D, Kuehn G, Kuehn T, Gillevet PM. Gut microbiome identifies risk for colorectal polyps. BMJ Open Gastroenterol. 2019;6:e000297. https://doi.org/10.1136/bmjgast-2019-000297

Dai X, Song D, Guo Q, Zhou W, Liu G, Ma R, Liang G, He P, Sun G, Yuan F, Liu Z. Predicting the influence of fertilization regimes on potential $N$ fixation through their effect on free-living diazotrophic community structure in double rice cropping systems. Soil Biol Biochem. 2021b;156:108220. https://doi.org/10.1016/j.soilbio.2021.108220

Dai Z, Hu J, Fan J, Fu W, Wang H, Hao M. No-tillage with mulching improves maize yield in dryland farming through regulating soil temperature, water and nitrate-N. Agric Ecosyst Environ. 2021a;309:107288. https://doi.org/10.1016/j.agee.2020.107288

Daraz U, Li Y, Sun Q, Zhang M, Ahmad I. Inoculation of Bacillus spp. modulate the soil bacterial communities and available nutrients in the rhizosphere of vetiver plant irrigated with acid mine drainage. Chemosphere. 2021;263:128345. https://doi.org/10.1016/j.chemosphere.2020.128345

Datta B, Chakrabartty PK. Siderophore biosynthesis genes of Rhizobium sp. isolated from Cicer arietinum L. 3 Biotech. 2014;4:391-401. https://doi.org/10.1007/s13205-013-0164-y 
Dazzo FB, Yanni YG. The natural Rhizobium-cereal crop association as an example of plant-bacterial interaction. In: Uphoff N, Ball AS, Fernandes E, Herren H, Husson O, Laing M, Palm C, Pretty J, Sanchez P, Sanginga N, Thies J, editors. Biological approaches to sustainable soil systems. Boca Raton: CRC Press; 2006. p. 109-27.

de Souza EM, Bassani VL, Sperotto RA, Granada CE. Inoculation of new rhizobial isolates improve nutrient uptake and growth of bean (Phaseolus vulgaris) and arugula (Eruca sativa). J Sci Food Agric. 2016;96:3446-53. https://doi.org/10.1002/jsfa.7527

de Souza EM, Lamb TI, Lamb TA, Silva AS, Carvalho SDF, Nyland V, Lopes MCB, Grohs M, Marconatto L, Borges LGA, Giongo A, Granada CE, Sperotto, RA. Rhizospheric soil from rice paddy presents isolable bacteria able to induce cold tolerance in rice plants. J Soil Sci Plant Nut. 2021;21:1993-2006. https://doi.org/10.1007/s42729-021-00496-y

Deka H, Deka S, Baruah CK. Plant growth promoting rhizobacteria for value addition: mechanism of action. In: Egamberdieva D, Shrivastava S, Varma A, editors. Plant-growth-promoting rhizobacteria (PGPR) and medicinal plants. New York: Springer; 2015. p. 305-21. https://doi.org/10. 1007/978-3-319-13401-7_15

Ditengou FA, Lapeyrie F. Hypaphorine from the ectomycorrhizal fungus Pisolithus tinctorius counteracts activities of indole-3-acetic acid and ethylene but not synthetic auxins in eucalypt seedlings. Mol Plant Microbe Interact. 2000;13:151-8. https://doi.org/10.1094/MPMI.2000.13.2.151.

Dobbelaere S, Vanderleyden J, Okon Y. Plant growth-promoting effects of diazotrophs in the rhizosphere. Crit Rev Plant Sci. 2003;22:107-49. https://doi.org/10.1080/713610853

Döring TF, Rosslenbroich D, Giese C, Athmann M, Watson C, Vágó I, Kátai J, Tállai M, Bruns C. Disease suppressive soils vary in resilience to stress. Appl Soil Ecol. 2020;149:103482. https://doi.org/10.1016/j.apsoil.2019.103482

Ferguson L, Lessenger JE. Plant growth regulators. In: Lessenger JE, editor. Agricultural medicine. New York: Springer; 2006. p. 156-66. https://doi.org/10.1007/0-387-30105-4_15

Finkel OM, Castrillo G, Paredes SH, González IS, Dangl JL. Understanding and exploiting plant beneficial microbes. Curr Opin Plant Biol. 2017;38:155-63. https://doi.org/10.1016/j.pbi.2017.04.018

Fu L, Penton CR, Ruan Y, Shen Z, Xue C, Li R, Shen Q. Inducing the rhizosphere microbiome by biofertilizer application to suppress banana Fusarium wilt disease. Soil Biol Biochem. 2017;104:39-48. https://doi.org/10.1016/j.soilbio.2016.10.008

Gadagi RS, Krishnaraj PU, Kulkarni JH, Sa T. The effect of combined Azospirillum inoculation and nitrogen fertilizer on plant growth promotion and yield response of the blanket flower Gaillardia pulchella. Sci Hortic. 2004;100:323-32. https://doi.org/10.1016/j.scienta.2003.10.002

Gang S, Sharma S, Saraf M, Buck M, Schumacher J. Analysis of indole-3-acetic acid (IAA) production in Klebsiella by LC-MS/MS and the Salkowski method. Bio Protocol. 2019;9:e3230. https://doi.org/10.21769/BioProtoc.3230

Gao H, Li S, Wu F. Impact of intercropping on the diazotrophic community in the soils of continuous cucumber cropping systems. Front Microbiol. 2021;12:630302. https://doi.org/10.3389/fmicb.2021.630302

Garbeva P, van Veen JA, van Elsas JD. Microbial diversity in soil: selection of microbial populations by plant and soil type and implications for disease suppressiveness. Annu Rev Phytopathol. 2004;42:243-70. https://doi.org/10.1146/annurev.phyto.42.012604.135455

Gebbers R, Adamchuk VI. Precision agriculture and food security. Science. 2010;327:828-31. https://doi.org/10.1126/science.1183899

Glick BR, Cheng Z, Czarny J, Duan J. Promotion of plant growth by ACC deaminase-producing soil bacteria. In: Bakker PAHM, Raaijmakers JM, Bloemberg G, Höfte M, Lemanceau P, Cooke BM, editors. New perspectives and approaches in plant growth-promoting rhizobacteria research. Dordrecht: Springer; 2007. p. 329-39. https://doi.org/10.1007/978-1-4020-6776-1_8 
Glick BR, Penrose DM, Li J. A model for the lowering of plant ethylene concentrations by plant growth-promoting bacteria. J Theor Biol. 1998;190:63-8.

https://doi.org/10.1006/jtbi.1997.0532

Grada A, Weinbrecht K. Next-generation sequencing: methodology and application. J Invest Dermatol. 2013;133:e11. https://doi.org/10.1038/jid.2013.248

Granada CE, Arruda L, Lisboa BB, Passaglia LMP, Vargas LK. Diversity of native rhizobia isolated in south Brazil and their growth promotion effect on white clover (Trifolium repens) and rice (Oryza sativa) plants. Biol Fertil Soils. 2014;50:123-32. https://doi.org/10.1007/s00374-013-0840-4

Granada CE, Costa PB, Lisboa BB, Vargas LK, Passaglia LMP. Comparison among bacterial communities present in arenized and adjacent areas subjected to different soil management regimes. Plant Soil. 2013;373:339-58. https://doi.org/10.1007/s11104-013-1796-8

Granada CE, Passaglia LM, Souza EM, Sperotto RA. Is phosphate solubilization the forgotten child of plant growth-promoting rhizobacteria? Frontiers Microbiol. 2018;9:2054. https://doi.org/10.3389/fmicb.2018.02054

He Y, Wu W, Zheng HM, Li P, McDonald D, Sheng HF, He Y, Wu W, Zheng HM, Li P, McDonald D, Sheng HF, Chen MX, Chen ZH, Ji GY, Zheng ZDX, Mujagond P, Chen XJ, Rong ZH, Chen P, Lyu LY, Wang X, Wu CB, Yu N, Xu YJ, Yin J, Raes J, Knight R, Ma WJ, Zhou HW. Regional variation limits applications of healthy gut microbiome reference ranges and disease models. Nat Med. 2018;24:1532-5. https://doi.org/10.1038/s41591-018-0164-X

Hsu SF, Buckley D. Evidence for the functional significance of diazotroph community structure in soil. ISME J. 2009;3:124-36. https://doi.org/10.1038/ismej.2008.82

Hu W, Samac DA, Liu X, Chen S. Microbial communities in the cysts of soybean cyst nematode affected by tillage and biocide in a suppressive soil. App Soil Ecol. 2017;119:396-406. https://doi.org/10.1016/j.apsoil.2017.07.018

Jenkinson DS. The soil microbial biomass. NZ Soil News. 1977;25:213-8.

Jo HW, Tagele SB, Pham HQ, Kim MC, Choi SD, Kim M-J, Park Y-J, Ibal JC, Park GS, Shin JH. Response of soil bacterial community and pepper plant growth to application of Bacillus thuringiensis KNU-07. Agronomy. 2020;10:551. https://doi.org/10.3390/agronomy10040551

Kamilaris A, Prenafeta-Boldú FX. Deep learning in agriculture: A survey. Comput Electron Agric. 2018;147:70-90. https://doi.org/10.1016/j.compag.2018.02.016

Khanghahi MY, Strafella S, Allegretta I, Crecchio C. Isolation of bacteria with potential plant-promoting traits and optimization of their growth conditions. Curr Microbiol. 2021;78:464-78. https://doi.org/10.1007/s00284-020-02303-w

Klein E, Katan J, Gamliel A. Soil suppressiveness to Fusarium disease following organic amendments and solarization. Plant Dis. 2011;95:1116-23. https://doi.org/10.1094/PDIS-01-11-0065

Kloepper J, Leong J, Teintze M, Schroth MN. Enhanced plant growth by siderophores produced by plant growth-promoting rhizobacteria. Nature. 1980;286:885-6. https://doi.org/10.1038/286885a0

Kloepper J, Schroth MN. Plant growth-promoting rhizobacteria on radishes. In: Proceedings of the 4th International conference on plant pathogenic bacteria; 1978 Aug. 27-Sept. 2; Angers, France. Angers: Station de Pathologie Vegetale et Phytobacteriologie; 1978. p. 879-82.

Li Y, Li T, Zhao D, Wang Z, Liao Y. Different tillage practices change assembly, composition, and co-occurrence patterns of wheat rhizosphere diazotrophs. Sci Total Environ. 2021;767:144252. https://doi.org/10.1016/j.scitotenv.2020.144252

Liakos KG, Busato P, Moshou D, Pearson S, Bochtis D. Machine learning in agriculture: A review. Sensors. 2018;18:2674. https://doi.org/10.3390/s18082674

Liao H, Li Y, Yao H. Fertilization with inorganic and organic nutrients changes diazotroph community composition and N-fixation rates. J Soils Sediments. 2018;18:1076-86. https://doi.org/10.1007/s11368-017-1836-8

Lisboa BB, Bayer C, Passaglia LMP, Camargo FAO, Beneduzi A, Ambrosini A, Vargas LK. Soil fungistasis against Fusarium graminearum under different crop management systems. Rev Bras Cienc Solo. 2015;39:69-77. https://doi.org/10.1590/01000683rbcs20150683 
Lisboa BB, Vargas LK, Silveira AO, Martins AF, Selbach PA. Indicadores microbianos de qualidade do solo em diferentes sistemas de manejo. Rev Bras Cienc Solo. 2012;36:33-44. https://doi.org/10.1590/S0100-06832012000100004

Lovley DR, Chapelle FH. Deep subsurface microbial processes. Rev Geophys. 1995;33:365-81. https://doi.org/10.1029/95RG01305

Lu Y, Wang E, Tang Z, Rui J, Li Y, Tang Z, Dong W, Liu X, George TS, Song A, Fan F. Roots and microbiome jointly drive the distributions of 17 phytohormones in the plant soil continuum in a phytohormone-specific manner. Plant Soil. 2021. https://doi.org/10.1007/s11104-021-04898-w

Ma Y. Editorial: Biotechnological potential of plant-microbe interactions in environmental decontamination. Front Plant Sci. 2019;10:1519. https://doi.org/10.3389/fpls.2019.01519

Martínez-Medina A, Roldán A, Albacete A, Pascual JA The interaction with arbuscular mycorrhizal fungi or Trichoderma harzianum alters the shoot hormonal profile in melon plants. Phytochemistry. 2011;72:223-9. https://doi.org/10.1016/j.phytochem.2010.11.008

Martins V, Silva DRG, Marchi G, Leite MCA, Martins ES, Gonçalves ASF, Guilherme LRG. Effect of alternative multinutrient sources on soil chemical properties. Rev Bras Cienc Solo. 2015;39:194-204. https://doi.org/10.1590/01000683rbcs20150587

Mawarda PC, Le Roux X, Van Elsas JD, Salles JF. Deliberate introduction of invisible invaders: a critical appraisal of the impact of microbial inoculants on soil microbial communities. Soil Biol Biochem. 2020;148:107874. https://doi.org/10.1016/j.soilbio.2020.107874

Mirza BS, Potisap C, Nüsslein K, Bohannan BJ, Rodrigues JL. Response of free-living nitrogen-fixing microorganisms to land use change in the Amazon rainforest. Appl Environ Microbiol. 2014;80:281-8. https://doi.org/10.1128/AEM.02362-13

Nannipieri P, Penton CR, Purahong W, Schloter M, van Elsas JD. Recommendations for soil microbiome analyses. Biol Fertil Soils. 2019;55:765-6. https://doi.org/10.1007/s00374-019-01409-z

Ortiz-Estrada AM, Gollas-Galván T, Martínez-Córdova LR, Martínez-Porchas M. Predictive functional profiles using metagenomic 16S rRNA data: a novel approach to understanding the microbial ecology of aquaculture systems. Rev Aquaculture. 2019;11:234-45. https://doi.org/10.1111/raq.12237

Pane C, Piccolo A, Spaccini R, Celano G, Villecco D, Zaccardelli M. Agricultural waste-based composts exhibiting suppressivity to diseases caused by the phytopathogenic soil-borne fungi Rhizoctonia solani and Sclerotinia minor. Appl Soil Ecol. 2013;65:43-51. https://doi.org/10.1016/j.apsoil.2013.01.002

Pastore G, Kaiser K, Kernchen S, Spohn M. Microbial release of apatite- and goethite-bound phosphate in acidic forest soils. Geoderma. 2020b;370:114360. https://doi.org/10.1016/j.geoderma.2020.114360

Pastore G, Kernchen S, Spohn M. Microbial solubilization of silicon and phosphorus from bedrock in relation to abundance of phosphorus-solubilizing bacteria in temperate forest soils. Soil Biol Biochem. 2020a;151:108050. https://doi.org/10.1016/j.soilbio.2020.108050

Poly F, Ranjard L, Nazaret S, Gourbière F, Monrozier LJ. Comparison of nifH gene pools in soils and soil microenvironments with contrasting properties. Appl Environ Microbiol. 2001;67:2255-62. https://doi.org/10.1016/10.1128/AEM.67.5.2255-2262.2001

Pothmann A, Illing T, Wiegand C, Hartmann AA, Elsner P. The microbiome and atopic dermatitis: A review. Am J Clin Dermatol. 2019;20:749-61. https://doi.org/10.1007/s40257-019-00467-1

Prudnikova S, Streltsova N, Volova T. The effect of the pesticide delivery method on the microbial community of field soil. Environ Sci Pollut Res. 2021;28:8681-97. https://doi.org/10.1007/s11356-020-11228-7

Reardon CL, Gollany HT, Wuest SB. Diazotroph community structure and abundance in wheat-fallow and wheat-pea crop rotations. Soil Biol Biochem. 2014;69:406-12. https://doi.org/10.1016/j.soilbio.2013.10.038

Ribeiro IDA, Volpiano CG, Vargas LK, Granada CE, Lisboa BB, Passaglia LMP. Use of mineral weathering bacteria to enhance nutrient availability in crops: a review. Front Plant Sci. 2020;11:590774. https://doi.org/10.3389/fpls.2020.590774 
Rossi W, Grappelli A, Pietrosanti W. Phytohormones in soil after atrazine application. Folia Microbiol. 1984;29:325-9. https://doi.org/10.1007/BF02875965

Saad RF, Kobaissi A, Echevarria G, Kidd P, Calusinska M, Goux X, Benizri E. Influence of new agromining cropping systems on soil bacterial diversity and the physico-chemical characteristics of an ultramafic soil. Sci Total Environ. 2018;645:380-92.

https://doi.org/10.1016/j.scitotenv.2018.07.106

São José JFB, Volpiano CG, Vargas LK, Hernandes MAS, Lisboa BB, Schlindwein G, Beneduzi A, Longoni LS, Sampaio JAT. Influence of hot water on breaking dormancy, incubation temperature and rhizobial inoculation on germination of Acacia mearnsii seeds. Aust Forestry. 2019;82:157-61. https://doi.org/10.1080/00049158.2019.1636350

Sarwar M, Arshad M, Martens DA, Martens DA, Frankenberger Jr WT. Tryptophan-dependent biosynthesis of auxins in soil. Plant Soil. 1992;147:207-15. https://doi.org/10.1007/BF00029072

Saulnier DM, Riehle K, Mistretta TA, Diaz MA, Mandal D, Raza S et al. Gastrointestinal microbiome signatures of pediatric patients with irritable bowel syndrome. Gastroenterology. 2011;141:1782-91. https://doi.org/10.1053/j.gastro.2011.06.072

Schlindwein G, Vargas LK, Lisboa BB, Azambuja AC, Granada CE, Gabiatti NC, Prates F, Stumpf R. Influence of rhizobial inoculation on seedling vigor and germination of lettuce. Cienc Rural. 2008;38:658-64. https://doi.org/10.1590/S0103-84782008000300010

Schmitt DE, Gatiboni LC, Orsoletta DJD, Brunetto G. Formation of ternary organic acidsFe-P complexes on the growth of wheat (Triticum aestivum). Rev Bras Eng Agric Ambient. 2018;22:702-6. https://doi.org/10.1590/1807-1929/agriambi.v22n10p702-706

Seneviratne CJ, Balan P, Suriyanarayanan T, Lakshmanan M, Lee DY, Rho M, Jakubovics N, Brandt B, Crielaard W, Zaura E. Oral microbiome-systemic link studies: perspectives on current limitations and future artificial intelligence-based approaches. Crit Rev Microbiol. 2020;46:288-99. https://doi.org/10.1080/1040841X.2020.1766414

Sessitsch A, Pfaffenbichler N, Mitter B. Microbiome applications from lab to field: Facing complexity. Trends Plant Sci. 2019;24:194-8. https://doi.org/10.1016/j.tplants.2018.12.004

Shahid M, Khan MS. Pesticide-induced alteration in proteins of characterized soil microbiota revealed by sodium dodecyl sulphate-polyacrylamide gel electrophoresis (SDS-PAGE). J Proteins Proteom. 2020;11:1-9. https://doi.org/10.1007/s42485-020-00028-9

Siegel-Hertz K, Edel-Hermann V, Chapelle E, Terrat S, Raaijmakers JM, Steinberg C. Comparative microbiome analysis of a Fusarium wilt suppressive soil and a Fusarium wilt conducive soil from the Chateaurenard region. Front Microbiol. 2018;9:568. https://doi.org/10.3389/fmicb.2018.00568

Silva UC, Medeiros JD, Leite LR, Morais DK, Cuadros-Orellana S, Oliveira CA, Lana UGP, Gomes EA, Santos VL. Long-term rock phosphate fertilization impacts the microbial communities of maize rhizosphere. Front Microbiol. 2017;8:1266. https://doi.org/10.3389/fmicb.2017.01266

Simon A, Sivasithamparam K. Pathogen-suppression: a case study in biological suppression of Gaeumannomyces graminis var. Tritici in soil. Soil Biol Biochem. 1989;21:331-7. https://doi.org/10.1016/0038-0717(89)90139-9

Smaill SJ, Leckie AC, Clinton PW, Hickson AC. Plantation management induces long-term alterations to bacterial phytohormone production and activity in bulk soil. Appl Soil Ecol. 2010;45:310-4. https://doi.org/10.1016/j.apsoil.2010.03.003

Solano BR, Maicas JB, Mañero FJG. Physiological and molecular mechanisms of plant growth promoting rhizobacteria (PGPR). In: Ahmad I, Pichtel J, Hayat S, editors. Plant-bacteria interactions: Strategies and techniques to promote plant growth. Weinheim: Wiley; 2008. p. 41-52. https://doi.org/10.1002/9783527621989.ch3

Souza R, Beneduzi A, Ambrosini A, Costa PB, Meyer J, Vargas LK, Schoenfeld R, Passaglia LMP. The effect of plant growth-promoting rhizobacteria on the growth of rice (Oryza sativa L.) cropped in southern Brazilian fields. Plant Soil. 2013;366:585-603. https://doi.org/10.1007/s11104-012-1430-1 
Souza RSC, Armanhi JSL, Arruda P. From Microbiome to traits: designing synthetic microbial communities for improved crop resiliency. Front Plant Sci. 2020;11:1179. https://doi.org/10.3389/fpls.2020.01179

Stockdale E, Brookes P. Detection and quantification of the soil microbial biomass - impacts on the management of agricultural soils. J Agric Sci. 2006;144:285-302. https://doi.org/10.1017/S0021859606006228

Tang Y, Zhang M, Chen A, Zhang W, Wei W, Sheng R. Impact of fertilization regimes on diazotroph community compositions and $\mathrm{N}_{2}$-fixation activity in paddy soil. Agric Ecosyst Environ. 2017;247:1-8. https://doi.org/10.1016/j.agee.2017.06.009

Tisdale SL, Nelson WL. Soil fertility and fertilizers. 3rd ed. New York: Macmillan Publishing; 1975.

Trivedi P, Delgado-Baquerizo M, Trivedi C, Hamonts K, Anderson IC, Singh BK. Keystone microbial taxa regulate the invasion of a fungal pathogen in agro-ecosystems. Soil Biol Biochem. 2017;111:10-4. https://doi.org/10.1016/j.soilbio.2017.03.013

Vargas LK, Scholles D. Biomassa microbiana e produção de $\mathrm{C}-\mathrm{CO}_{2}$ e $\mathrm{N}$ mineral de um Podzólico Vermelho-Escuro submetido a diferentes sistemas de manejo. Rev Bras Cienc Solo. 2000;24:35-42. https://doi.org/10.1590/S0100-06832000000100005

Vargas LK, Volpiano CG, Lisboa BB, Giongo A, Beneduzi A, Passaglia LMP. Potential of rhizobia as plant growth-promoting rhizobacteria. In: Khan MS, Zaide A, Musarrat J, editors. Microbes for legume improvement. 2nd ed. Berlin: Springer; 2017. p. 153-74. https://doi.org/10.1007/978-3-319-59174-2_7

Verma P, Yadav AN, Khannam KS, Saxena AK, Suman A. Potassium-solubilizing microbes: diversity, distribution, and role in plant growth promotion. In: Panpatte DG, Jhala YK, Vyas RV, Shelat HN, editors. Microorganisms for green revolution: Microbes for sustainable crop production. Singapore: Springe; 2017. p. 125-49. https://doi.org/10.1007/978-981-10-6241-4_7

Vessey JK. Plant growth promoting rhizobacteria as biofertilizers. Plant Soil. 2003;255:571-86. https://doi.org/10.1023/A:1026037216893

Volpiano CG, Lisboa BB, São José JFB, Oliveira AMR, Beneduzi A, Passaglia LMP, Vargas LK. Rhizobium strains in the biological control of the phytopathogenic fungi Sclerotium (Athelia) rolfsii on the common bean. Plant Soil. 2018;432:229-43. https://doi.org/10.1007/s11104-018-3799-y

Weller DM, Raaijmakers JM, Gardener BBM, Thomashow LS. Microbial populations responsible for specific soil suppressiveness to plant pathogens. Annu Rev Phytopathol. 2002;40:309-48. https://doi.org/10.1146/annurev.phyto.40.030402.110010

Willems A. The taxonomy of rhizobia: An overview. Plant Soil. 2006;287:3-14. https://doi.org/10.1007/s11104-006-9058-7

Xiao D, Liu X, Yang R, Tan Y, Zhang W, He X, Xu Z, Wang K. Nitrogen fertilizer and Amorpha fruticosa leguminous shrub diversely affect the diazotroph communities in an artificial forage grassland. Sci Total Environ. 2020;711:134967. https://doi.org/10.1016/j.scitotenv.2019.134967

Xie K, Guo L, Bai Y, Liu W, Yan J, Bucher M. Microbiomics and plant health: An interdisciplinary and international workshop on the plant microbiome. Mol Plant. 2019;12:1-3. https://doi.org/10.1016/j.molp.2018.11.004

Xiong W, Li R, Ren Y, Liu C, Zhao Q, Wu H, Jousset A, Shen Q. Distinct roles for soil fungal and bacterial communities associated with the suppression of vanilla Fusarium wilt disease. Soil Biol Biochem. 2017;107:198-207. https://doi.org/10.1016/j.soilbio.2017.01.010

Yadav B, Verma A. Phosphate solubilization and mobilization in soil through microorganisms under arid ecosystems. In: Alí M, editor. The functioning of ecosystems. Rijeka: Intech; 2012. p. 93-108. https://doi.org/10.5772/35917

Yang H, Li J, Xiao Y, Gu Y, Liu H, Liang Y, Liu X, Hu J, Meng D, Yin H. An integrated insight into the relationship between soil microbial community and tobacco bacterial wilt disease. Front Microbiol. 2017;8:2179. https://doi.org/10.3389/fmicb.2017.02179

Yang L, Bai J, Zeng N, Zhou X, Liao Y, Lu Y, Rees RM, Nie J, Cao W. Diazotroph abundance and community structure are reshaped by straw return and mineral fertilizer in rice-rice-green manure rotation. Appl Soil Ecol. 2019;136:11-20. https://doi.org/10.1016/j.apsoil.2018.12.015 
Yang T, Evans B, Bainard LD. Pulse frequency in crop rotations alters soil microbial community networks and the relative abundance of fungal plant pathogens. Front Microbiol. 2021;12:667394. https://doi.org/10.3389/fmicb.2021.667394

Yousef N. Capability of plant growth-promoting rhizobacteria (PGPR) for producing indole acetic acid (IAA) under extreme conditions. Eur J Biol Res. 2018;8:174-82. https://doi.org/10.5281/zenodo.1412796

Zerrouk IZ, Rahmoune B, Khelifi L, Mounir K, Baluska F, Ludwig-Müller J. Algerian Sahara PGPR confers maize root tolerance to salt and aluminum toxicity via ACC deaminase and IAA. Acta Physiol Plant. 2019;41:91. https://doi.org/10.1007/s11738-019-2881-2

Zhang X, Ervin EH, Evanylo GK, Haering K. Impact of biosolids on hormone metabolism in drought-stressed tall fescue. Crop Sci. 2009;49:1893-901. https://doi.org/10.2135/cropsci2008.09.0521

Zheng M, Zhou Z, Luo Y, Zhao P, Mo J. Global pattern and controls of biological nitrogen fixation under nutrient enrichment: a meta-analysis. Glob Chang Biol. 2019;25:3018-30. https://doi.org/10.1111/gcb.14705

Zheng Y, Han X, Zhao D, Wei K, Yuan Y, Li Y, Liu M, Zhang C-S. Exploring biocontrol agents from microbial keystone taxa associated to suppressive soil: a new attempt for a biocontrol strategy. Front Plant Sci. 2021;12:655673. https://doi.org/10.3389/fpls.2021.655673

Zou J, Yao Q, Liu J, Li Y, Song F, Liu X, Wang G. Changes of diazotrophic communities in response to cropping systems in a Mollisol of Northeast China. Peer]. 2020;8:e9550. https://doi.org/10.7717/peerj.9550 